\title{
Investigation of antiproliferative effects of Hypericum perforatum oil on myelo- ma cells
}

\author{
Soner TUTUN ${ }^{1}$, Muhammet Mükerrem KAYA², Melike Sultan USLUER ${ }^{2}$, Hidayet TUTUN ${ }^{2}$
}

${ }^{1}$ Burdur Mehmet Akif Ersoy University, Healthcare and Biomedical Sciences, Burdur/TURKEY

${ }^{2}$ Burdur Mehmet Akif Ersoy University, Veterinary Faculty, Department of Pharmacology and Toxicology, Burdur/TURKEY

Key Words:

antiproliferative activity

hypericum perforatum

myeloma cells

\section{Anahtar Kelimeler: antiproliferatif etkinlik hypericum perforatum myeloma hucreleri}

Received : 29.04.2020 Accepted: 22.06 .2020

Published Online: 29.08.2020

Article Code:728975

Correspondence:

MS. USLUER

(melikeusluer.15@gmail.com)

ORCID:

S. TUTUN : :0000-0002-6208-476X MM. KAYA : 0000-0002-7781-5342 MS. USLUER : 0000-0002-9391-2839 H. TUTUN : :0000-0001-9512-8637

\begin{abstract}
St. Johns wort (Hypericum perforatum) is a medicinal plant that exhibits important biological activities exhibit important biological activities being antioxidant, anti-inflammatory, immunomodulatory and/ or antitumour. The aim of this study was to investigate antiproliferative effect of $H$. perforatum oil purchased from a commercial vendor on mouse myeloma cells. The cells were treated with various concentration $(10 \%, 5 \%, 2 \%, 1 \%, 0.5 \%, 0.25 \%, 0.2 \%$ and $0.1 \%$ ) of dimethyl sulfoxide (DMSO) to determine the non-toxic concentration. The cells were treated with various concentrations (15.6-500 $\mathrm{ppm}$ ) of the oil dissolved in DMSO to examine its antiproliferative activity. Non-toxic dose of DMSO was at the concentration of lower than $0.2 \%$. No effect on the cell proliferation was observed in the applied concentration of the oil. In conclusion, the oil had no antiproliferative effect on Myeloma cells at these concentrations.
\end{abstract}

\section{Hypericum perforatum yağının myeloma hücrelerinde antiproliferatif aktivitesinin araştırılması \\ ÖZ}

Sar1 Kantaron (Hypericum perforatum), antioksidan, antiinflamatuar, immünomodülatör ve/veya antitümör gibi önemli biyolojik aktiviteler sergileyen tıbbi bir bitkidir. Bu çalışmanın amacı, lokal bir marketten satın alınan sarı kantaron yağının fare myeloma hücreleri üzerine antiproliferatif etkisini incelemektir. Toksik olmayan konsantrasyonu belirlemek için DMSO Myeloma hücrelerine çeşitli konsantrasyonlarda $(\% 10, \% 5, \% 2, \% 1, \% 0,5, \% 0,25, \% 0,2$ ve $\% 0,1)$ uyguland. DMSO içerisinde çeşitli konsantrasyonlarda (15,6-500 ppm) çözdürülen yağ, myeloma hücrelerine karşı antiproliferatif etkinliğini incelemek için uygulandi. Toksik olmayan DMSO dozu, \%0,2'den daha düşük bir konsantrasyondaydı. Uygulanan konsantrasyonlardaki yağ hücre çoğalması üzerine herhangi bir etki göstermedi. Sonuç olarak, yağın bu dozlarda Myeloma hücreleri üzerinde antiproliferatif etki göstermemiştir.

\section{INTRODUCTION}

Multiple myeloma (MM), known as the uncontrolled, destructive growth of plasma cells within the bone marrow, is a lethal hematological B cell malignancy and characterized by a monoclonal immunoglobulin fraction in serum or urine, kidney failure, and osteolytic bone lesions (1-3). MM is the second most common hematologic malignancy and constitutes about 1\% (120 000 cases per year) of all neoplastic cancers and $13 \%$ of hematological cancers (4). According to the data of the International Agency for Research on Cancer (IARC), the number of cases in 2018 was 159985 (5). According to the National Cancer Institute, it was reported that 1.8\% (32 110 cases) of all cancer cases were MM in the USA in 2019 (6). As the median age at diagnosis is approximately 70 years and the world population ages due to increased life expectancy and low fertility levels, it is expected that these numbers will increase to approximately 350000 cases by the year 2050 (7).

Complementary and Alternative Medicine (CAM) is a group of diagnostic and therapeutic disciplines that extend beyond conventional Western medical treatments and includes a wide range of products such as herbs, vitamins, minerals, and probiotics, and diverse practices such as acupuncture (8). Though alternative medicine refers to therapies used in place of proven standard medical treatment, complementary medicine is used together with conventional medicine $(9,10)$. It has been reported that the prevalence of usage of CAM among cancer patients was found to be $51 \%$ and the patients of younger age, female sex, higher education and income were more likely to use CAM (11).

St. John's wort, known as Hypericum perforatum (HP), grows in every continent in the world, except Antarctica. In traditional Turkish medicine, it is used in treatment of ulcers, diabetes mellitus, flu, digestive system diseases, jaundice, liver and gallbladder diseases (12). Previous studies have reported that various extracts of $\mathrm{HP}$ or its active constituents had antidepressant (13), antiviral (14), antimicrobial $(15,16)$, antiinflammatory (17), gastroprotective (18), antifungal (19), apoptotic (20) and wound healing activities (21). HP contains hypericin, hyperforin, hyperoside, rutin, quercetin, isoquercitrin, naphthodiantrons, phloroglucinol, amentoflavone, biapigenin, caffeic acid, chlorogenic acid, procyanidins and kaempferol $(22,23)$. 
It has been reported that hyperforin inhibited the growth of breast carcinoma (24). However, ethanol extract of HP had no cytotoxic effect on human cervical adenocarcinoma (HeLa) cells (25). There are very few studies on the study of the effect of St. John's Wort oil on cancer cells. Therefore, the purpose of the present study is to investigate the antiproliferative effect of HP oil on myeloma cells.

\section{MATERIALS AND METHODS}

\section{Cell culture}

Myeloma (F0 ATCC CRL-1646) cell line was cultured in Dulbecco's Modified Eagle's Medium (DMEM) containing 10\% FBS (Fetal bovine serum), 0.1\% gentamicin, 1\% sodium pyruvate and $2 \%$ L-glutamine in a cell incubator (Steri-Cycle i160, Thermo Scientific) at $37^{\circ} \mathrm{C}$, in $5 \% \mathrm{CO}_{2}$ and $95 \%$ relative humidity. Dimethyl sulfoxide (DMSO, less than $0.2 \%$ ) was used to dissolve St. John's Wort oil purchased from local market homogeneously in the medium.

\section{Determination of non-toxic DMSO concentration}

M T T ( 3 - [ 4,5-di m e th y l th i a z o le - 2 - Y L ] -2,5-diphenyltetrazolium bromide) assay was used to assess the effect of these concentration of DMSO on viability of myeloma cell line (26). DMSO was dissolved in DMEM medium and diluted in the medium to prepare appropriate concentrations $(10 \%, 5 \%, 2 \%, 1 \%, 0.5 \%, 0.25 \%, 0.2 \%$ and $0.1 \%$ ). The cells were seeded at a density of $3 \times 10^{5}$ cells $/ \mathrm{mL}$ and then incubated with different concentrations of DMSO for 24 hours. After incubation, MT'T solution $(5 \mathrm{mg} / \mathrm{ml}$ in PBS) was added to each well with a final amount of $0.5 \mathrm{mg} / \mathrm{ml}$. The plate was incubated in $5 \% \mathrm{CO}_{2}$ incubator for about 3 hours. Then, MT'T solution was removed and $150 \mu$ of DMSO was added to each well to dissolve the purple formazan crystals. After formazan derivates was dissolved, absorbances were measured at $570 \mathrm{~nm}$ with a microplate spectrophotometer (Multiskan Go, Thermo Scientific).

\section{Cell viability assay}

St. John's Wort oil (Hypericum perforatum) was purchased at a local market in Burdur province of Turkey. MTT test was used to determine the effect of the oil on viability of myeloma cells (26). The cells were seeded in 96-well plates $\left(3 \times 10^{5}\right.$ cells/ $\mathrm{mL}$ ) and cultured in $5 \% \mathrm{CO}_{2}$ incubator at $37^{\circ} \mathrm{C}$ overnight. The oil was dissolved in DMSO at the concentration of lower than $0.2 \%$. The oil $(500,250,125.5,62.5,31.25,15.625 \mathrm{ppm}$ in DMEM) was incubated for 24 hours. The medium only and $0.1 \%$ Triton X-100 served as negative and positive controls, respectively. MT'T was added to each well with a final amount of $0.5 \mathrm{mg} / \mathrm{ml}$ and incubated for about 3 hours in the incubator at $37^{\circ} \mathrm{C}$. Then, MTT solution was removed from the wells. 150 $\mu$ of DMSO was added to each well to dissolve the purple formazan crystals and the plate was kept on a horizontal shaker (Thermo scientific) for 30 minutes. Absorbances were measured at $570 \mathrm{~nm}$ with a microplate spectrophotometer (Multiskan Go, Thermo Scientific).

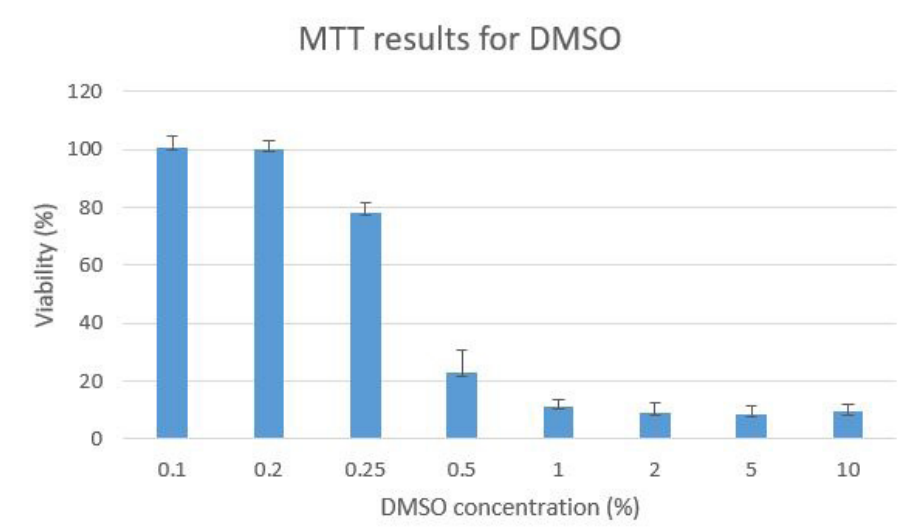

Figure 1. Effects of the oil of $\mathrm{H}$. perforatum on the proliferation of Myeloma cells.

\section{Statistical analysis}

Each concentration of the oil and DMSO on viability of the cell was evaluated in triplicate.

\section{RESULTS}

We determined the non-toxic dose of DMSO used to dissolve the oil on Myeloma cells. The results of the study showed that DMSO had any toxic effects on the myeloma cells, with the final concentration of DMSO of $0.2 \%$ and below (Figure 1). Determining the antiproliferative activity of St. John's Wort oil on myeloma, the amount of DMSO remained below these percentages. The growth of Myeloma cells was assessed by the MT'T test. The results of the test showed that the oil of $H$. perforatum had not antiproliferative activity against Myeloma cells at concentrations of 500 to 15.625 ppm for 24 hours.

\section{DISCUSSION}

Cancer is one of the most common causes of mortality in the world today (27). Although a large number of drugs are used in the treatment of the cancer, these drugs are not sufficient to completely control the cancer and show serious side effects that are unpredictable and linked to chemotherapeutic agents for patients (28-30). Exploring plant oils, extracts and active compounds having anticancer activities seems to be a vital strategy for the development of new anticancer agents with different mode of action or lower toxic effects. St. John's Wort has been used widely in folk medicine to treat several disorders including depression (31), peptic ulcers (32), wound (33) for thousands of years. Recently, it has gained a greater popularity as an anti-depressant for moderate depressive symptoms in humans (34). After the discovery of these pharmacological activities, a large number of studies have begun to investigate the effects of various extracts and active components of the plant (35-37). However, there are limited studies on apoptotic and anticancer effects of its active ingredients and extracts of the plant $(20,38,39)$.

In a study, it has been reported that the water extract of ethanolic dry extracts of the John's Wort exhibited antiproliferative effects on human cervix adenocarcinoma 
(HeLa) cells at concentrations greater than 200 ppm (IC50) (25). It has been shown that the essential oil of Hypericum hircinum had antiproliferative effect on human glioblastoma (T98G), human prostatic adenocarcinoma (PC3), human squamous carcinoma (A431) and mouse melanoma (B16-F1) cancer cell lines and the 50\% inhibitory concentration (IC50) for these cell lines ranged from 63.7 to 117.2 ppm after 72 $\mathrm{h}$ of incubation (38). Our previous study has indicated the apoptotic activity of ethanolic extract of $\mathrm{HP}$ against Human breast cancer cells (MCF-7) (20). Another study has demonstrated that methanolic extract of $H$. perforatum and its purified active component hypericin had high and weak inhibitory effect on growth of human erythroleukemic cell line (K562), respectively (39). According to the MT'T results in this study, treated concentrations of the oil did not show any antiproliferative effects in myeloma cells at 24 hours in the applied concentrations of commercial St. John's Wort oil. Regarding the antiproliferative activities of the St. John's Wort, the findings of the present study are not correlation with the findings of most studies. Unlike other studies, the absence of antiproliferative effect of the oil on Myeloma cells at the treated concentrations may be due to the different cell line used and/or the low quality of the purchased oil or the oil of this plant does not have any antiproliferative effect on the cells.

\section{CONCLUSION}

The oil of $H$. perforatum did not exhibit antiproliferative activity against the Myeloma cells at 24 hours.

\section{DECLARATIONS}

\section{Ethics approval and consent to participate}

Not applicable

\section{Consent for publication}

Not applicable

\section{Availability of data and material}

Not applicable.

\section{Competing interests}

The authors declare that they have no competing interests.

\section{Funding}

There is no funding for this work.

\section{Authors' contributions}

HT, MSU, MMK and ST performed the MT'T test to analysis the growth of Myeloma cells treated with oil of Hypericum perforatum. HT interpreted the data regarding the viability test. ST was a major contributor in writing the manuscript. All authors read and approved the final manuscript.

\section{Acknowledgements}

Not applicable

\section{REFERENCES}

1. Hideshima T, Mitsiades C, Tonon G, Richardson PG, Anderson KC. Understanding multiple myeloma pathogenesis in the bone marrow to identify new therapeutic targets. Nat Rev Cancer. 2007;7(8):585-98.

2. Wang J, Hendrix A, Hernot S, Lemaire M, De Bruyne E, Valckenborgh EV, et al. Bone marrow stromal cell-derived exosomes as communicators in drug resistance in multiple myeloma cells. Blood. 2014;124(4):555-66.

3. Ríos-Tamayo R, Rodríguez DS, Chang-Chan YL, Pérez MJS. Epidemiology of Multiple Myeloma. In Update on Multiple Myeloma. IntechOpen. (2018).

4. Raab MS, Podar K, Breitkreutz I, Richardson PG, Anderson KC Multiple myeloma. Lancet. 2009;374:324-39.

5. World Health Organization. https://www.who.int/ news-room/fact-sheets/detail/cancer 2018. Erişim tarihi:20.02.2020.

6. National Cancer Institute (NCI). Cancer Stat Facts: Myeloma. https:/./seer.cancer.gov/statfacts/html/mulmy. html. Erişim tarihi:20.02.2020.

7. Ludwig H, Miguel JS, Dimopoulos MA, Palumbo A, Sanz $\mathrm{RG}$, Powles R, et al. International Myeloma Working Group recommendations for global myeloma care. Leukemia. 2014;28;981-92.

8. Gottschling S, Meyer S, Längler A, Scharifi G, Ebinger F, Gronwald B. Differences in use of complementary and alternative medicine between children and adolescents with cancer in Germany: a population based survey. Pediatr Blood Cancer. 2014; 61:488-92.

9. National Cancer Institute (NCI), (2018). Definition of Complementary and Alternative Medicine CAM according to the National Center for Complementary and Integrative Health. https://nccih.nih.gov/health/integrative-health. Erişim tarihi: 24. 02. 2020.

10. Tabish SA. Complementary and alternative healthcare: is it evidence-based? International journal of health sciences. 2008;2(1):V-IX.

11. Keene MR, Heslop IM, Sabesan SS, Glass BD. Complementary and alternative medicine use in cancer: a systematic review. complementary therapies in clinical practice. 2019;35:33-47.

12. Baytop T. Therapy with Herbs in Turkey, Publication No. 3255. Istanbul Univ. Press, Istanbul, 1984 pp. 185-6.

13. Barnes J, Anderson LA, Phillipson JD. St John's wort (Hypericum perforatum L.): a review of its chemistry, pharmacology and clinical properties. J Pharm Pharmacol. 2001;53(5):583-600.

14. Weber ND, Murray BK, North JA, Wood SG. The antiviral agent hypericin has in vitro activity against HSV-1 through non-specific association with viral and cellular membranes. Antivir. Chem. Chemother. 1994;5:83-90. 
15. Nezhad SK, Zenouz AT, Aghazadeh M, Kafil HS. Strong antimicrobial activity of Hypericum perforatum L. against oral isolates of Lactobacillus spp. Cell. Mol. Biol.(Noisy-le-grand). 2017;63:58-62.

16. Fiebich B, Heinrich M, Langosch JM, Kammerer N, Lieb K. Antibacterial activity of hyperforin from St John's wort. Lancet. 1999;354:777.

17. Savikin K, Dobrić S, Tadić V, Zdunić G. Antiinflammatory activity of ethanol extracts of Hypericum perforatum L., H. barbatum Jacq., H. hirsutum L., H. richeri Vill. and H. androsaemum L. in rats. Phytother Res: PTR. 2007;21(2):176180 .

18. Zdunić G, Gođevac D, Milenković M, Vučićević D, Šavikin $\mathrm{K}$, Menković N, et al. Evaluation of Hypericum perforatum oil extracts for an antiinflammatory and gastroprotective activity in rats. Phytother Res. 2009;23(11):1559-64.

19. Angiolella L, Carradori S, Maccallini C, Giusiano G, T Supuran C. Targeting Malassezia species for novel synthetic and natural antidandruff agents. Curr. Med. Chem. 2017;24(22):2392-412.

20. Alp H, Tutun H, Kaplan HM, Şingirik E, Altıntaş L. Investigation of apoptotic effects of Hypericum perforatum extract on breast cancer cell line. Harran Üniv Vet Fak Derg. 2019;8(2):198-202.

21. Yadollah-Damavandi S, Chavoshi-Nejad M, Jangholi E, Nekouyian N, Hosseini S, Seifaee A, et al. Topical Hypericum perforatum improves tissue regeneration in fullthickness excisional wounds in diabetic rat model. Evid-Based Complementary Altern. Med. 2015;245-328.

22. Surmuş Asan H. The Studies on The endemic Hypericum Species from Turkey, Batman univ. yaşam bilim. derg. 2019;9(2):253-68.

23. Dolezal AG, St Clair AL, Zhang G, Toth AL, O’Neal ME. Native habitat mitigates feast-famine conditions faces by honey bees in an agricultural landscape. PNAS. 2019;116(50):25147155.

24. Schempp CM, Kirkin V, Simon-Haarhaus B, Kersten A, Kiss J, Termeer CC, et al. Inhibition of tumour cell growth by hyperforin, a novel anticancer drug from St. John's wort that acts by induction of apoptosis. Oncogene. 2002;21(8):124250 .

25. Cenić-Milošević D, Tambur Z, Ivančajić S, Stanojković T, Grozdanić N, Kulišić Z, et al. Antiproliferative effects of Tanaceti partheni, Hypericum perforatum and propolis on HeLa cells. Arch. Biol. Sci. 2014;66(2):705-12.

26. Mosmann T. Rapid colorimetric assay for cellular growth and survival application to proliferation and cytotoxicity assays. J. Immunol. Methods. 1983;65:55-63.

27. Fitzmaurice C, Dicker D, Pain A, Hamavid H, MoradiLakeh M, MacIntyre MF, et al. The global burden of cancer 2013. JAMA oncology. 2015;1(4):505-27.

28. LeBaron S, Zeltzer L. Behavioral intervention for reducing chemotherapy-related nausea and vomiting in adolescents with cancer. J Adolesc Health. 1984;5(3):178-82.

29. Morrow GR. The effect of a susceptibility to motion sickness on the side effects of cancer chemotherapy. Cancer. 1985;55(12):2766-70.

30. Qin SY, Cheng YJ, Lei Q, Zhang AQ, Zhang XZ. Combinational strategy for high-performance cancer chemotherapy. Biomaterials. 2018;171:178-97.

31. Laakmann G, Jahn G, Schüle C. Hypericum perforatum extract in treatment of mild to moderate depression. Clinical and pharmacological aspects. Nervenarzt. 2002;73(7):600-12.

32. Cayci MK, Dayioglu H. Hypericum perforatum extracts healed gastric lesions induced by hypothermic restraint stress in Wistar rats. Saudi Med J. 2009;30(6):750-4.

33. Süntar IP, Akkol EK, Yılmazer D, Baykal T, Kırmızıbekmez $\mathrm{H}$, Alper $\mathrm{M}$, et al. Investigations on the in vivo wound healing potential of Hypericum perforatum L. J Ethnopharmacol. 2010;127(2):468-77.

34. Reichling J, Weseler A, Saller R. A current review of the antimicrobial activity of Hypericum perforatum L. Pharmacopsychiatry. 2001;34(Sup. 1):116-8.

35. Altıparmak M, Eskitaşçıŏlu T. Comparison of systemic and topical Hypericum perforatum on diabetic surgical wounds. J Invest Surg. 2018;31(1):29-37.

36. Selek S, Esrefoglu M, Meral I, Bulut H, Caglar HG, Sonuc $G$, et al. Effects of Oenothera biennis L. and Hypericum perforatum L. extracts on some central nervous system myelin proteins, brain histopathology and oxidative stress in mice with experimental autoimmune encephalomyelitis. Biotech Histochem. 2019;94(2):75-83.

37. Yechiam E, Ben-Eliezer D, Ashby NJ, Bar-Shaked M. The acute effect of Hypericum perforatum on short-term memory in healthy adults. Psychopharmacology. 2019;236(2):613-23.

38. Quassinti L, Lupidi G, Maggi F, Sagratini G, Papa F, Vittori $\mathrm{S}$, et al. Antioxidant and antiproliferative activity of Hypericum hircinum L. subsp. majus (Aiton) N. Robson essential oil. Nat Prod Res. 2013;27(10):862-8.

39. Roscetti G, Franzese O, Comandini A, Bonmassar E. Cytotoxic activity of Hypericum perforatum L. on K562 erythroleukemic cells: differential effects between methanolic extract and hypericin. Phytother Res. 2004;18(1):66-72. 